\title{
Acoustic analysis of swallowing as an auxiliary method for assessing dysphagia in
}

\section{Parkinson's disease}

\author{
Análise acústica da deglutição como método auxiliar para avaliar a disfagia na doença de Parkinson \\ Análisis acústico de la deglución como método auxiliar para evaluar la disfagia en la enfermedad de
}

\section{Parkinson}

Glauce Souza da Silva

ORCID: https://orcid.org/0000-0002-9398-1367

University Tuiuti of Paraná, Brazil

E-mail: glaucesouza9@hotmail.com

Ana Clara Gonçalves de Figueiredo ORCID: https://orcid.org/0000-0003-4154-9991

University Tuiuti of Paraná, Brazil

E-mail: figueiredo.anaclarag@gmail.com

Bianca Simone Zeigelboim

ORCID: https://orcid.org/0000-0003-4871-2683

University Tuiuti of Paraná, Brazil

E-mail: bianca.zeigelboim@utp.br

Cristiano Miranda de Araújo

ORCID: https://orcid.org/0000-0003-1325-4248

University Tuiuti of Paraná, Brazil

E-mail: cristiano.araujo@utp.br

José Stechmann Neto

ORCID: https://orcid.org/0000-0002-0259-2420

University Tuiuti of Paraná, Brazil

E-mail: jose.stechmann@utp.br

Rosane Sampaio Santos

ORCID: https://orcid.org/0000-0001-6400-5706

University Tuiuti of Paraná, Brazil

E-mail: rosane.santos2@utp.br

\begin{abstract}
Objective: To measure the accuracy of DeglutiSom as an auxiliary method to assess swallowing in patients with Parkinson's disease (PD). Methodology: Accuracy study. Among 248 individuals, 91 participants met the inclusion criteria, with a mean age of 64.9 years (SD 7.7), 53.8\% male and $46.2 \%$ female, with a mean disease duration of 12.6 years (SD 3.8 years). Two instrumental studies were performed: An acoustic analysis with Sonar Doppler via the DeglutiSom Software, and a videofluoroscopic swallow study. Three judges analyzed the swallowing sounds in the DeglutiSom software and the instrumental examination findings. Results: The inter-rater reliability was $90.1 \%$, with $4.4 \%$ degree of partial agreement and 5.5\% disagreement. Sensitivity resulted in $90.0 \%$ and specificity in $90.0 \%$. A sensitivity of $97.0 \%$ and specificity of $91.0 \%$ are indicators of a high validity for the dysphagia screening method, with predictive value (+) of $97.0 \%$ and predictive value (-) of $91.0 \%$, with an accuracy method of $96.0 \%$. The validity indicator values for screening aspiration were also high, with a sensitivity of $90.0 \%$, specificity of $90.0 \%$, predictive value $(+)$ of $82.0 \%$, predictive value (-) of $95 \%, 0 \%$ and $90.0 \%$ accuracy. Conclusion: The method proposed is considered appropriate for oropharyngeal dysphagia and tracheal aspiration screening in patients with Parkinson's Disease.
\end{abstract}

Keywords: Swallowing; Swallowing disorders; Parkinson's disease; Doppler effect; Speech-language pathology.

\section{Resumo}

Objetivo: Medir a precisão do DeglutiSom como um método auxiliar para avaliar a deglutição em pacientes com doença de Parkinson (DP). Metodologia: Estudo da exatidão. Entre 248 indivíduos, 91 participantes preencheram os critérios de inclusão, com uma idade média de 64,9 anos (DP 7,7), 53,8\% homens e 46,2\% mulheres, com uma duração média da doença de 12,6 anos (DP 3,8 anos). Foram realizados dois estudos instrumentais: Uma análise acústica com Sonar 
Doppler por meio do Software DeglutiSom, e um estudo de deglutição videofluoroscópica. Três juízes analisaram os sons da deglutição no software DeglutiSom e os resultados do exame instrumental. Resultados: A confiabilidade entre os examinadores foi de $90,1 \%$, com 4,4\% de concordância parcial e 5,5\% de discordância. A sensibilidade resultou em $90,0 \%$ e a especificidade em 90,0\%. Uma sensibilidade de $97,0 \%$ e especificidade de $91,0 \%$ são indicadores de uma alta validade para o método de triagem da disfagia, com valor preditivo (+) de $97,0 \%$ e valor preditivo (-) de $91,0 \%$, com um método de precisão de $96,0 \%$. Os valores dos indicadores de validade para a aspiração de triagem também foram altos, com uma sensibilidade de $90,0 \%$, especificidade de $90,0 \%$, valor preditivo (+) de $82,0 \%$, valor preditivo (-) de $95 \%, 0 \%$ e 90,0\% de precisão. Conclusão: O método proposto é considerado apropriado para a triagem da disfagia orofaríngea e da aspiração traqueal em pacientes com a doença de Parkinson.

Palavras-chave: Deglutição; Transtornos de deglutição; Doença de Parkinson; Efeito Doppler; Patologia da fala e linguagem.

\section{Resumen}

Objetivo: Medir la precisión del DeglutiSom como método auxiliar para evaluar la deglución en pacientes con enfermedad de Parkinson (EP). Método: Estudio de precisión. Entre 248 individuos, 91 participantes cumplieron los criterios de inclusión, con una edad media de 64,9 años (SD 7,7), 53,8\% hombres y 46,2\% mujeres, con una duración media de la enfermedad de 12,6 años (SD 3,8 años). Se realizaron dos estudios instrumentales: Un análisis acústico con Sonar Doppler a través del Software DeglutiSom, y un estudio de deglución videofluoroscópico. Tres jueces analizaron los sonidos de la deglución en el software DeglutiSom y los resultados del examen instrumental. Resultados: La fiabilidad entre jueces fue del $90,1 \%$, con un $4,4 \%$ de grado de acuerdo parcial y un 5,5\% de desacuerdo. La sensibilidad resultó del $90,0 \%$ y la especificidad del $90,0 \%$. Una sensibilidad del $97,0 \%$ y una especificidad del $91,0 \%$ son indicadores de una alta validez para el método de cribado de la disfagia, con un valor predictivo (+) del 97,0\% y un valor predictivo (-) del 91,0\%, con un método de precisión del 96,0\%. Los valores de los indicadores de validez para el cribado de la aspiración también fueron elevados, con una sensibilidad del 90,0\%, una especificidad del 90,0\%, un valor predictivo $(+)$ del $82,0 \%$, un valor predictivo (-) del 95\%, y una precisión del 90,0\%. Conclusiones: El método propuesto se considera adecuado para el cribado de disfagia orofaríngea y aspiración traqueal en pacientes con Enfermedad de Parkinson.

Palabras clave: Deglución; Trastornos de la deglución; Enfermedad de Parkinson; Efecto Doppler; Patología del habla y del lenguaje.

\section{Introduction}

Parkinson's disease is a chronic and progressive disorder of the central nervous system, characterized by the degeneration of dopaminergic neurons, which may affect the dorsal nucleus of the vagus nerve. Authors estimate an incidence of 36,000 new cases per year in the Brazilian population, with a prevalence of 3.3\% in individuals over 64 years of age (Souza et al., 2011).

Although it is primarily a motor impairment disease, dysphagia can also be present in Parkinson's disease, albeit not always correlated to the severity of the disease. The literature shows that dysphagia affects more than $80 \%$ of individuals with Parkinson's disease (Luchesi et al., 2015) and affects all swallowing phases: oral, pharyngeal, and esophageal (Kim et al.,). Thus, early diagnosis and prognosis of dysphagia is important to improve management and reduce its associated morbidity and mortality, according to the American Speech-Language-Hearing Association [ASHA] (2004).

Early identification of dysphagia should be performed by a screening instrument. There is currently no consensus on the parameters that should make up a screening instrument and who should complete it. Many studies do not report the steps required to construct a measuring instrument, which includes obtaining evidence of instrument validity (Edmiaston et al., 2014).

This proposed method has not been performed in other populations and will be the first study measuring DeglutiSom's accuracy in screening dysphagia with Parkinson's disease patients.

Cervical auscultation by Sonar Doppler associated with acoustic swallowing analysis is a non-invasive technique, without radiation exposure, of easy applicability and low cost, with credibility gain in clinical swallowing evaluation (Santos \& Macedo Filho, 2006; Taveira et al., 2018). 
The acoustic analysis method with Sonar Doppler measures swallowing sounds, which provide audible clues that can help the dysphagia screening process (Madalozzo et al., 2017). Computer programs analyze the signals received and provide quantitative data, including parameters related to the duration, frequency, and intensity of the sound (Almeida, 2013).

When selecting an appropriate study instrument, professionals should take into consideration the concepts of validity, reliability, sensitivity, specificity, and predictive values, as well as performing a validation according to the target population (Goulart \& Chiari, 2007; Menezes \& Nascimento, 2000). The present study aims to measure the accuracy of DeglutiSom as an auxiliary method to assess swallowing in patients with Parkinson's disease.

\section{Methodology}

This is an accuracy study approved by the Research Ethics Committee under protocol No.00051 / 2008.

Inclusion criteria were: Individuals with Parkinson's disease, both genders, age over 18 years, complaining of oropharyngeal dysphagia, responsive to verbal and simple commands, and who agreed to participate in the study. Exclusion criteria were: Patients with other neurological conditions, with an inability of oral intake, and with any oropharyngeal or laryngeal structural abnormalities.

Two simultaneous assessments were performed: Swallowing assessment by capturing acoustic analysis via the Sonar Doppler and DeglutiSom Software, and an instrumental assessment by videofluoroscopy (reference method).

During the swallowing evaluation, the researcher (1), responsible for the study, registered the data in the software and evaluated the audio signals, fundamental frequency, and intensity, along with the videofluoroscopy images. The Acoustic Deglutition Assessment Protocol was used as a reference (Madalozzo et al., 2017).

The instrumental videofluoroscopic evaluation was coupled to the acoustic assessment of swallowing by Sonar Doppler, which was recorded on the DeglutiSom software. Researcher (2), a dysphagia specialist, performed the simultaneous analysis of the swallowing sounds and videofluoroscopy images according to the swallowing severity scale (Ott, Hodge, Pikna, Chen \& Gelfand, 1996). The Matlab software was used to determine the transition points of the swallowing phases identified in the swallowing acoustic signals. The Matlab software is based on Simulink and DPS System Toolbox.

After the two evaluations, three Dysphagia Specialized Speech-Language Pathologists were invited to analyze the swallowing sounds in the DeglutiSom software and, subsequently, to evaluate the findings of the instrumental exam.

\section{Sonar Doppler}

Swallowing was assessed with a portable Sonar Doppler (AngelSounds model, Jumper brand) with a continuous flat disk transducer. The device operates on two batteries and features an individual transducer, with a headphone, recorder, and computer output. The Doppler ultrasound frequency is $3 \mathrm{MHz}$, with output of $10 \mathrm{~mW} / \mathrm{cm}^{2}$. The sound output power is $1 \mathrm{~W}$.

The continuous Doppler equipment was coupled to an HP standard notebook, sound card, and speakers. The operating system used was Windows 7®. The DeglutiSom ${ }^{\circledR}$ software, developed by Engefono in 2014, and validated in 2021 (Enz et al., 2021), was used to record the acoustic signals and later analyze them (Figure 1). 
Figure 1 - DeglutiSom ${ }^{\circledR}$ Software.

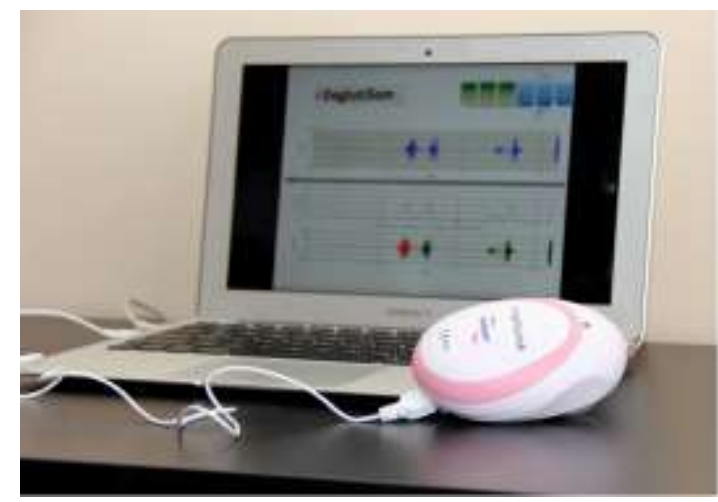

Source: Authors (2018).

For the process of capturing swallowing sounds, subjects were instructed to remain seated in a chair, with the cervical region in ventral flexion (simulating a normal meal position) and with free access to the neck.

The Sonar Doppler transducer was positioned in the right lateral region of the neck, on the lateral edge of the trachea and just below the cricoid cartilage, considered the best place for cervical auscultation (Takahashi et al., 1994) (Figure 2).

Figure 2 - Localization for swallowing sounds.

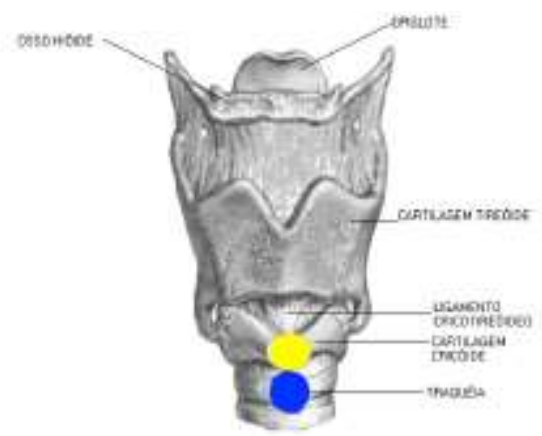

Source: Takahashi, Groher e Michi (1994). Based and adapted from Almeida (2013).

The ultrasonic energy beam emitted by the transducer was positioned to form an angle of $30^{\circ}$ to $60^{\circ}$. Contact gel was used at the transducer application site for the dispersion of the ultrasound in the air and to increase its transmission in the body.

A number of three swallowing samples were taken for each solid, liquid and pudding food consistency. The dietary consistencies used for swallowing assessment followed the American Dietetic Association standard (American Dietetic Association (ADA, 2017): Liquid: $70 \mathrm{ml}$ water and $30 \mathrm{ml}$ barium Guedert (10-50 Cp); Pudding: $70 \mathrm{ml}$ water, $30 \mathrm{ml}$ barium Guedert and $10 \mathrm{~g}$ Resource Thicken up thickener (over $1751 \mathrm{Cp}$ ); and Solid: Club Social cracker soaked in barium Guedert.

Subjects were instructed to swallow only after the evaluator's signal - about three seconds after the transducer was positioned in the right lateral region of the neck.

Each bolus was required to be swallowed in a single swallow $(30 \mathrm{ml})$. A three-minute interval was observed for swallowing sounds to begin to pick up from one consistency to the next. 
In the acoustic analysis of the swallowing sound signal, recordings were captured in the DeglutiSom ${ }^{\circledR}$ software, which allowed analysis using the following functions: Audio signal: for measuring swallowing time in seconds; Fundamental Frequency: recorded in $\mathrm{Hz}$, with the frequency window between 0 and $6000 \mathrm{~Hz}$; Intensity: recorded in $\mathrm{dB}$, with window between 0 and 1000 dB (Figure 3).

Figure 3 - Swallowing sound curve representation.

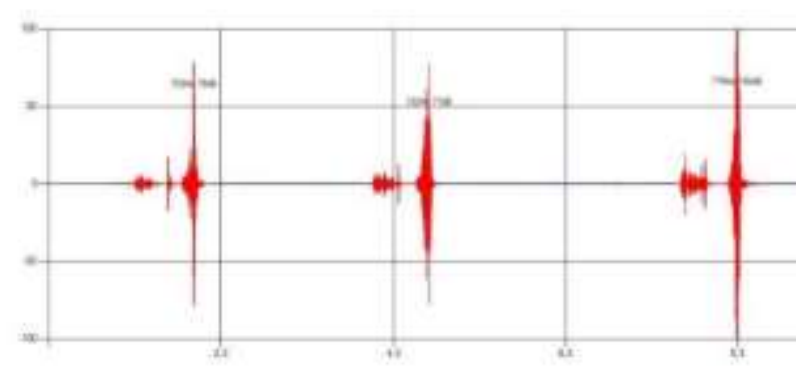

Source: Acoustic analysis of the DeglutiSom ${ }^{\circledR}$ Software.

The Doppler equipment's volume was adjusted for the best acoustic signal pickup and the lowest external noise interference, with three minutes of signal pickup.

The swallowing sound variables were: acoustic signal frequency [sound wave frequency (Fo) measured in $\mathrm{Hz}$ ]; the intensity of the acoustic signal [sound wave intensity (I) measured in $\mathrm{dB}$ ] and the time elapsed from the beginning to the end of the analyzed acoustic signal [swallowing time $(\mathrm{T})$ measured by audio signal in seconds].

Three swallowing samples were performed to profile the swallowing sounds. The samples indicated auditory representation (acoustic signal) and visual representation (frequency and intensity graph). The data were stored for comparison.

\section{Videofluoroscopic Instrumental Evaluation}

The Siemens X-ray Model Axiom R100 and the Siemens monitor M44-2 were used for the videofluoroscopic swallowing study. Images were scanned to an HP Pavilion Tx 2075BR notebook through the Sapphire Worder TV USB TV Capture card.

During the evaluation, the individual was seated, and, without the use of local anesthesia, the exam was performed in the lateral position. The Guerdert liquid barium contrast was used for videofluoroscopic visualization, which allowed a better delimitation of the structures involved in the swallowing biomechanics.

To maintain standardization in the examinations, three volumes of the same dietary order and consistency were offered (ADA, 2017) during both the instrumental swallow evaluation and the Doppler Sonar. The examination was suspended in case the individual had nausea, vomiting or any clinical instability.

The oral phase presented the following: Bolus intake; labial seal; the positioning/ preparation/chewing of the bolus; anterio-posterior (A-P) transport of the bolus; oral and pharyngeal phase coordination; extraoral escape and oral cavity residue after swallowing. These stages were rated as present or absent for extraoral escape and oral cavity residual, and as efficient and inefficient for the other stages (Hamlet et al., 1994). 
The efficiency of velopharyngeal seal and "asymmetry in laryngeal descent" were observed in the pharyngeal phase of swallowing. The following were rated as present or absent: laryngeal penetration; tracheal aspiration; valleculae residue; pyriform residue (Marik \& Zaloga, 2001). Cricopharyngeal opening in the transition from the pharyngeal to the esophageal phase.

The results of the videofluoroscopic swallow study were classified by the Gravity Scale proposed by Ott et al (1996).

Swallowing sounds and videofluoroscopy images were analyzed using the Matlab® software, based on the Simulink ${ }^{\circledR}$ and DPS System ${ }^{\circledR}$ Toolbox, to determine the transition points of the swallowing phases identified in the swallowing acoustic signal (Figure 4). Data were analyzed with the XXX Engineering Course.

Figure 4 - Matlab® software for swallowing sound signal analysis on swallowing videofluoroscopy image.

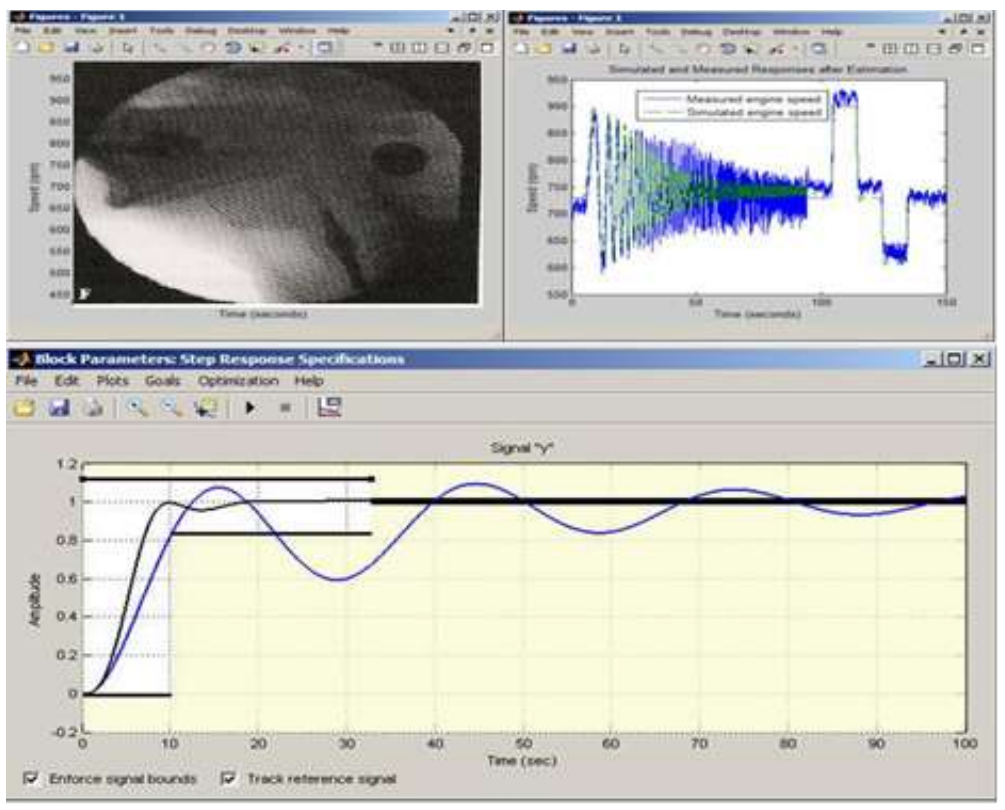

Source: Matlab® software.

\section{Judges Evaluation}

The board was composed of three dysphagia-specialized speech-language pathologists who have worked in the area for more than five years and who use acoustic analysis of swallowing.

All judges who agreed to participate in the study signed the Free and Informed Commitment Term and were trained to perform swallowing acoustic analysis using the DeglutiSom® software.

It is noteworthy that the results of the acoustic analysis of the Sonar Doppler were sent randomly, without the judges' knowledge of the severity of swallowing or disease.

Each judge answered yes or no whether the patient had altered swallowing according to the findings obtained in the DeglutiSom Software, and whether the patient presented with acoustic signals suggestive of laryngotracheal aspiration. These two questions were part of the Acoustic Deglutition Assessment Protocol (Madalozzo et al., 2017) questionnaire.

Descriptive (mean, minimum, maximum, and standard deviation) and inferential methods (tests at a significance level of 0.05 and 95\% confidence intervals) were used. The agreement between the judges was verified through the Kappa test. The following indicators were used: sensitivity, specificity, positive predictive value, negative predictive value, and accuracy. 
The KR-20 Coefficient developed by Kuder and Richardson was used for the reliability analysis. This was a replacement for Cronbach's Alpha Coefficient when the variables are dichotomous (yes/no). The softwares used for the analyzes were Statistica - Version 13.3, and Matlab R12.

\section{Results}

The study was conducted at the XXXX Department of the Public Hospital, from February 2016 to December 2017. A total of 248 individuals were evaluated and 91 individuals with a medical diagnosis of idiopathic Parkinson's disease were selected, according to the selection criteria and to the disease staging scale (Hoehn \& Yahr, 1967). Out of 91 subjects, 42 were females and 49 males, aged between 50 and 78 years, average of 64.9 years $( \pm 7.7)$, with mean time disease diagnosis of $12.6( \pm 3.8)$. The sample size (91 patients) corresponded to a confidence level of $95.0 \%$ with a sampling error of $3.0 \%$ and a test power of $83 \%$.

Table 1 shows the results obtained in the swallowing acoustic analysis concomitantly with the videofluoroscopy findings. In the pharyngeal phase - laryngeal elevation and cricopharyngeal opening - the results of the comparison between the frequencies of swallowing sounds between frequency 1 peak (F1p) and intensity 1 peak (1p) dB, final frequency (FF) in $\mathrm{Hz}$ and final intensity, showed significant changes in frequencies, means, minimum, maximum, and standard deviation.

Table 1 - Distribution of the comparison of swallowing sounds with videofluoroscopy.

\begin{tabular}{|c|c|c|c|c|c|}
\hline Result & $\mathrm{N}$ & Mean & Minimum & Maximum & Standard Deviation \\
\hline \multicolumn{6}{|c|}{ ORAL PHASE - BOLUS INTAKE } \\
\hline \multicolumn{6}{|c|}{ Initial Frequency (IF) in $\mathrm{Hz}$} \\
\hline Efficient & 60 & 485,58 & 101,00 & 580,44 & 140,96 \\
\hline Not efficient & 31 & 420,02 & 297,44 & 549,99 & 54,65 \\
\hline All & 91 & 463,25 & 101,00 & 580,44 & 122,47 \\
\hline \multicolumn{6}{|c|}{ Initial Intensity (II) in $\mathrm{dB}$} \\
\hline Efficient & 60 & 48,04 & 39,06 & 56,00 & 5,03 \\
\hline Not efficient & 31 & 48,23 & 30,50 & 56,69 & 5,74 \\
\hline All & 91 & 48,10 & 30,50 & 56,69 & 5,25 \\
\hline \multicolumn{6}{|c|}{ PHARYNGEAL PHASE - LARYNGEAL ELEVATION } \\
\hline \multicolumn{6}{|c|}{ Frequency 1 peak $(\mathrm{F} 1 \mathrm{P})$ in $\mathrm{Hz}$} \\
\hline Present & 42 & 607,61 & 310,50 & 768,79 & 94,88 \\
\hline Reduced & 23 & 517,15 & 360,0 & 690,0 & 90,96 \\
\hline Reduced & 26 & Absent & Absent & Absent & Absent \\
\hline All & 91 & 575,60 & 310,50 & 768,79 & 102,53 \\
\hline \multicolumn{6}{|c|}{ Intensity 1 peak (I1P) in $\mathrm{dB}$} \\
\hline Present & 42 & 65,98 & 50,00 & 90,00 & 7,97 \\
\hline Reduced & 23 & 58,47 & 50,00 & 70,00 & 5,90 \\
\hline Reduced & 26 & Absent & Absent & Absent & Absent \\
\hline All & 91 & 63,32 & 50,00 & 90,00 & 8,11 \\
\hline \multicolumn{6}{|c|}{ PHARYNGEAL PHASE - CRICOPHARYNGEAL OPENING } \\
\hline \multicolumn{6}{|c|}{ Final Frequency $(\mathrm{FF})$ in $\mathrm{Hz}$} \\
\hline Present & 79 & 712,86 & 101,00 & 1010,50 & 224,52 \\
\hline Altered & 12 & 575,83 & 389,05 & 796,44 & 113,66 \\
\hline All & 91 & 694,79 & 101,00 & 1010,50 & 217,81 \\
\hline \multicolumn{6}{|c|}{ Final Intensity $(\mathrm{FI})$ in $\mathrm{dB}$} \\
\hline Present & 79 & 79,67 & 51,00 & 95,00 & 11,12 \\
\hline Altered & 12 & 65,84 & 2,20 & 97,56 & 15,40 \\
\hline All & 91 & 77,85 & 50,00 & 97,56 & 12,58 \\
\hline \multicolumn{6}{|c|}{ Swallowing time in seconds } \\
\hline Present & 79 & 2,63 & 1,30 & 3,40 & 0,46 \\
\hline Increased & 12 & 2,68 & 2,20 & 3,20 & 0,31 \\
\hline All & 91 & 2,65 & 1,30 & 3,40 & 0,45 \\
\hline
\end{tabular}

Label: Hertz= Hz; Decibel= Db. Source: Authors (2018). 
In the videofluoroscopic swallow study, individuals with Parkinson's disease were classified according to the degree of dysphagia by the Ott et al. Scale (Ott et al., 1996). A prevalence of individuals with moderate dysphagia was observed (41.7\%) (Table 2).

Table 2 - Sample distribution according to the Ott scale22 $(\mathrm{n}=91)$.

\begin{tabular}{l|c|c}
\hline \multicolumn{1}{c|}{ OTT SCALE } & FREQUENCY & PERCENTAGE \\
\hline Normal & 7 & $7,7 \%$ \\
Mild Dysphagia & 20 & $22,0 \%$ \\
Moderate Dysphagia & 38 & $41,7 \%$ \\
Severe Dysphagia & 26 & $28,6 \%$ \\
\hline
\end{tabular}

Source: Authors (2018).

Table 3 shows the comparison between the presence of dysphagia and the acoustic signal of laryngotracheal aspiration, compared to the videofluoroscopic swallow study and considered by the severity scale. It was found that in moderate and severe dysphagia, laryngotracheal aspiration occurred within the different dietary consistencies evaluated. Due to the limited number of individuals who accepted the solid consistency diet, it was decided not to address its results in the study.

Table 3 - Sample distribution relating dysphagia with acoustic signals.

\begin{tabular}{cccc}
\hline & \multicolumn{2}{c}{ PUDDING CONSISTENCY $(\mathrm{n}=91)$} & FREQUENCY \\
\hline DYSPHAGIA & TRACHEAL ASPIRATION & SEVERITY & $7(7,7 \%)$ \\
Yes & Yes & Moderate & $26(28,6 \%)$ \\
Yes & Yes & Severe & $4(4,4 \%)$ \\
Yes & No & Mild & $31(34,0 \%)$ \\
Yes & No & Moderate & $7(7,7 \%)$ \\
No & No & Normal & $16(17,6 \%)$ \\
No & No & Mild & \\
\hline & LIQUID CONSISTENCY (n=68) & FREQUENCY \\
\hline DYSPHAGIA & TRACHEAL ASPIRATION & SEVERITY & $26(38,2 \%)$ \\
Yes & Yes & Moderate & $4(5,9 \%)$ \\
Yes & Yes & Severe & $31(45,6 \%)$ \\
Yes & No & Mild &
\end{tabular}

Source: Authors (2018).

Table 4 shows the results of the three judges regarding the Ott scale (Ott et al., 1996), used in the videofluoroscopic swallow study, and the aspiration of the research subjects. There was agreement on the results between the judges.

Table 4 - Relationship between the Ott scale22 and aspiration between judges and researcher.

\begin{tabular}{l|c|c|c|c|c|c|c|c}
\hline \multirow{2}{*}{ OTT } & \multicolumn{2}{c|}{ JUDGE 1 } & \multicolumn{2}{c|}{ JUDGE 2 } & \multicolumn{2}{c|}{ JUDGE 3 } & \multicolumn{2}{c}{ RESEARCHER } \\
\cline { 2 - 9 } & \multicolumn{2}{c|}{ Tracheal Aspiration } & \multicolumn{2}{c}{ Tracheal Aspiration } & \multicolumn{2}{c}{ Tracheal Aspiration } & \multicolumn{2}{c}{ Tracheal Aspiration } \\
\cline { 2 - 9 } & Yes & No & Yes & No & Yes & No & Yes & No \\
\hline Normal & - & 7 & - & 7 & - & 7 & - & 7 \\
Mild & - & 20 & - & 20 & - & 20 & - & 20 \\
Moderate & 4 & 34 & 3 & 35 & 3 & 35 & 7 & 31 \\
Severe & 26 & - & 26 & - & 26 & - & 33 & 58 \\
Total & 30 & 61 & 29 & 62 & 29 & 62 & - \\
\hline
\end{tabular}

Source: Authors (2018). 
Regarding the indicators of sensitivity, specificity, positive predictive value, negative predictive value and accuracy for validation analysis and dysphagia screening method, the results are presented in the dysphagia screening (Table 5).

Table 5 - Accuracy analysis indicators for dysphagia and aspiration screening.

\begin{tabular}{lcc}
\hline \multicolumn{1}{c}{ DYSPHAGIA INDICATOR } & RESULT & CONCLUSION \\
\hline Sensibility & $0,97(97,0 \%)$ & High \\
Specificity & $0,91(91,0 \%)$ & High \\
Predictive Value (+) & $0,97(97,0 \%)$ & High \\
Predictive Value (-) & $0,91(91,0 \%)$ & High \\
Accuracy & $0,96(96,0 \%)$ & High \\
\hline \multicolumn{1}{c}{ ASPIRATION INDICATOR } & RESULT & CONCLUSION \\
\hline Sensibility & $0,90(90,0 \%)$ & High \\
Specificity & $0,90(90,0 \%)$ & High \\
Predictive Value (+) & $0,82(82,0 \%)$ & High \\
Predictive Value (-) & $0,95(95,0 \%)$ & High \\
Accuracy & $0,90(90,0 \%)$ & High \\
\hline
\end{tabular}

Source: Authors (2018).

It is observed that the method presents positive and adequate results in the dysphagia screening.

\section{Discussion}

In clinical practice, the search for diagnostic and rehabilitative instruments of swallowing disorders has become increasingly frequent. The present study sought to measure the accuracy of acoustic analysis as an auxiliary method for swallowing assessment in patients with Parkinson's disease.

The literature reports that early identification of oropharyngeal dysphagia should be performed using a screening instrument to determine the need for a comprehensive swallowing assessment. This instrument should be accessible to speechlanguage pathologists involved in patient care, because, in case of risk of dysphagia, patients should be referred for further evaluation (Almeida et al., 2017). Studies show that $80 \%$ of individuals with Parkinson's Disease present with dysphagia (Luchesi et al., 2015). The wide range of dysphagia prevalence in patients with Parkinson's disease may be caused by various definitions of dysphagia, and differences in assessment techniques, disease duration, and severity (Pflug et al., 2018).

Among the 91 individuals (100\%), 38 (41.7\%) presented with a Moderate Dysphagia in the instrumental videofluoroscopic swallow study, according to the Ott scale (Ott et al., 1996). One study considered the videofluoroscopy exam as a swallowing evaluation reference (Taveira et al., 2018), but research mentions that the ultrasound exam can also be applied to visualize the temporal relationship between structural movements of the oral and pharyngeal phases of swallowing (Pflug et al., 2018).

Instruments such as accelerometers, software, Sonar Doppler and microphones can also be used as a complementary exam. These instruments assess sounds associated with swallowing, in order to identify specific acoustic characteristics and possible aspiration signals (Almeida, 2013; Santos \& Macedo Filho, 2006; Soria et al., 2016).

The cervical auscultation method is promising, since it is not invasive and can be used in clinical evaluations (Feerrucci et al., 2013). However, further studies are needed to validate this method.

A current systematic review (Taveira et al., 2018) analyzed the validity of different diagnostic methods for assessing swallowing sounds when compared to videofluoroscopy, to detect oropharyngeal dysphagia. It was observed that the use of Doppler presented as an excellent method of acoustic analysis with sound capture. 
The methodology of the present study is supported by the literature and shows that the use of Sonar Doppler is already being adopted by researchers in the field of dysphagia. Therefore, this type of research is deemed important in helping the speechlanguage pathologist understand and properly diagnose dysphagia in the cases of Parkinson's disease.

The instrumental videofluoroscopic assessment was coupled with the acoustic swallowing assessment by Sonar Doppler and the data were recorded in the DeglutiSom software. The speech-language pathologist responsible for the analysis had experience in dysphagia. Of note, the solid consistency diet was not addressed in the study, as many study subjects refused to eat it. In the pharyngeal phase, laryngeal elevation and cricopharyngeal opening showed significant changes in frequencies, means, minimum, maximum, and standard deviation. The frequencies of swallowing sounds were between frequency 1 peak (F1p) and intensity 1 peak (I1p) dB, final frequency (FF) in $\mathrm{Hz}$ and final intensity.

The swallowing function of the healthy elderly with presbyphagia may present with slower muscle movement, dysfunction of the cricopharyngeal sphincter and pharyngeal closure, reduced laryngeal elevation, and increased swallowing time (Soria et al., 2016). These findings have not been reported in later studies in individuals with Parkinson's disease.

The prevalence rates of dysphagia in patients with Parkinson's disease are known to range from 70\% to 100\% (Luchesi et al., 2015). The present study found a prevalence of moderate oropharyngeal dysphagia in this population. This data was also reported by $40 \%$ of individuals with Parkinson's disease who underwent videofluoroscopy exam (Sebben et al., 2013).

During the evaluation process, 23 individuals did not present with dysphagia on pudding consistency, thus did not receive a liquid diet. When observing the relationship between the presence of dysphagia on videofluoroscopy and the acoustic signal of laryngotracheal aspiration, it was found that in subjects with moderate and severe dysphagia, laryngotracheal aspiration occurred throughout the different dietary consistencies tested.

Studies report that the reliability or accuracy of an instrument is the ability to reproduce similar measurements when performed by the same or different examiners (Goulart \& Chiari, 2007; Menezes, 1998; Menezes \& Nascimento, 2000). Therefore, it is important to validate instruments according to the target population, and it is essential to provide information about the sensitivity, specificity, and predictive values of the instrument (Goulart \& Chiari, 2007).

Considering the importance of the reliability of the proposed instrument, judges were selected with expertise in dysphagia and practicing in the area for more than five years. Of note, the results of the Sonar Doppler acoustic analysis were randomized, without knowledge of the severity of dysphagia or the disease.

The three judges agreed when assessing the relationship between the Ott scale (Ott et al., 1996) and the aspiration signs of individuals with Parkinson's disease.

Sensitivity, specificity, predictive value (positive and negative) and accuracy for validation analysis are important indicators for validating a screening instrument. The indicators for validity analysis of the dysphagia screening method were as follows: $97.0 \%$ sensitivity, $91.0 \%$ specificity, positive predictive value $97.0 \%$ and negative predictive value $91 \%$. These values suggest that the dysphagia screening instrument proposed is a valid screening tool.

The indicators for validity analysis of the aspiration screening method were as follows: $90.0 \%$ sensitivity, $90.0 \%$ specificity, positive predictive value $82.0 \%$ and negative predictive value $95.0 \%$. One realizes that knowledge of assessment tools, whether in diagnosis or screening; clinical examinations, or evaluations; is increasingly available in the market, but adequate parameters are not always found to contribute to the assessment process (Potvin et al., 2005). 
The standardization of swallowing sounds as a screening instrument is quite promising in the field of speech-language pathology. However, studies are still needed in the swallowing evaluation process and in the subjective observations of swallowing (Almeida, 2013; Santos \& Macedo Filho, 2006; Soria et al., 2016).

It is suggested to use acoustic analysis in a rehabilitation study, evaluating the analysis parameters obtained by Sonar Doppler and the DeglutiSom software in individuals with other underlying diseases, comparing the results of dysphagia therapy from the patient's perception.

\section{Conclusion}

The purpose of this study was to measure the accuracy of acoustic analysis as an auxiliary method for swallowing assessment in patients with Parkinson's disease.

Swallowing acoustic parameters of individuals with Parkinson's disease obtained by Sonar Doppler and the DeglutiSom® software, were identified by the evaluators and compared to the videofluoroscopic swallowing study used as a reference exam.

The method presents appreciable results in dysphagia screening and identifying the presence of acoustic signal of laryngotracheal aspiration. The values obtained indicated the accuracy of the method as a dysphagia screening tool, with $97.0 \%$ sensitivity and $91.0 \%$ specificity. The values obtained indicated validity of the method as an aspiration screening tool, with $90.0 \%$ sensitivity and $90.0 \%$ specificity and $75.0 \%$ accuracy.

\section{References}

Almeida, S. T. (2013). Análise Acústica da deglutição e do segmento pós- deglutição de crianças com disfagia orofaríngea e aspiração traqueal. Tese (Doutorado em Ciências em Gastroenterologia e Hepatologia) - Universidade Federal do Rio Grande do Sul. Faculdade de Medicina. Porto Alegre, 2013.

Almeida, T. M., Cola, P. C., Pernambuco, D. A., Junior, H. V. M. M., Magnoni, C. D., \& Silva, R. G. D. (2017). Screening tool for oropharyngeal dysphagia in Stroke - Part I: evidence of validity based on the content and response processes. CoDAS. 29(4): e20170009. 10.1590/2317-1782/20172017009.

American Dietetic Association. (2017). Food and nutrition misinformation: position of ADA. J Am Diet Assoc. 102:260-66.

American Speech-language-hearing Association (ASHA). Preferred practice patterns for the profession of speech-language pathology. Rockville: ASHA, 2004.

Edmiaston, J., Connor, L. T., Steger-May, K., \& Ford, A. L. (2013). A simple bedside stroke dysphagia screen, validated against videofluoroscopy, detects dysphagia and aspiration with high sensitivity. J Cerebrovasc Dis Stroke. 23:712-16.

Enz, V. C. Q., Vaz, A. R. C., Nunes, M. C. A., Rosa, M. O., Nunes, J. A., Marques, J. M., \& Santos, R. S. (2021). Accuracy of Acoustic Evaluation of Swallowing as a Diagnostic Method of Dysphagia in Individuals Affected by Stroke: Preliminary Analysis. Dysphagia https://doi.org/10.1007/s00455-021-10358-5

Feerrucci, J. L., Mangilli, L. D., Sassi, F. C., Limongi, S. C. O., \& Andrade, C. R. F. (2013). Sons da deglutição na prática fonoaudiológica: análise crítica da literatura. Einstein. 11:535-39.

Goulart, B. N. G., \& Chiari, B. M. (2007). Testes de rastreamento x testes de diagnóstico: atualidades no contexto da atuação fonoaudiológica. Pró-Fono R. Atual. 19:223-32.

Hamlet, S. L., Penney, D. G., \& Formolo, J. (1994). Stethoscope acoustics and cervical auscultation of swallowing. Dysphagia.9:63-8.

Hoehn, M. M., \& Yahr, M. D. (1967) Parkinsonism: onset, progression and mortality. Neurology.,17:427-42.

Kim, Y. H., Oh, B. M., Jung, I. Y., Lee, J. C., Lee, G. J., \& Han, T. R. (2015). Spatiotemporal characteristics of swallowing in Parkinson's disease. Laryngoscope. 125:389-95.

Linch, C. D. S. (2008) Análise da fisiologia da deglutição por meio da ultra-sonografia. 2008. 142 f. Tese (Doutorado em Ciências) - Faculdade de Medicina. Universidade de São Paulo.

Luchesi, K. F., Kitamura, S., \& Mourão, L. F. (2015). Progressão e tratamento da disfagia na doença de Parkinson: estudo observacional. Braz J Otorhinolaryngol. $81: 24-30$.

Madalozzo, B., Aoki, M. C. S., Soria, A. F., Santos, S. R., \& Furkim, A. M. (2017). Análise acústica do tempo de deglutição através do Sonar Doppler. Rev. CEFAC. 19:350-59. 
Marik, P. E., \& Zaloga, G. P. Early enteral nutrition in acutely ill patients: a systematic review. Crit. Care Med. 2001,29:2264-70.

Menezes, P. R., \&Nascimento, A. F. Validade e confiabilidade das escalas de avaliação em psiquiatria. Em: Gorenstein C, Andradelhs, Zuardiaw. Escalas de avaliação clínica em psiquiatria e psicofarmacologia. Lemos editorial, 2000:23-8.

Menezes, P. R., Nascimento, A. F. Validade e confiabilidade das escalas de avaliação em psiquiatria. Em: Gorenstein C, Andrade LHS, Zuardi AW. Escalas de avaliação clínica em psiquiatria e psicofarmacologia. Lemos editorial, 2000:23-8.

Menezes, P. R. Validade e confiabilidade das escalas de avaliação em psiquiatria. Rev. psiquiatr. clín. 1998,25:214-16.

Ott, D., Hodge, R. G., Pikna, L. A., Chen, M. Y., \& Gelfand, D. W. Modified barium swallow: clinical and radiographic correlation and relation to feeding recommendations. Dysphagia. 1996,11:93-8.

Pflug, C., Bihler, M., Emich, K., Niessen, A., Nienstedt, J. C., Flugel, T., et al. Critical dysphagia is common in Parkinson disease and occurs even in early stages: a prospective cohort study. Dysphagia. 2018,33:41-50.

Potvin, L., Gendron, S., Bilodeau, S., \& Chabot, P. Integrating social theory into public health practice. Am J Public Health. 2005,95:591-95.

Santos, R. S., \& Macedo Filho, E. D. Sonar Doppler como instrumento de avaliação da deglutição. Int. Arch. Otorhinolaryngol. 2006,10:182-91.

Sebbena, C., Zartb, P., Ardenghic, L. G., Varellad, A. C. D. O., Paimd, E. D., Matosd, M. S., et al. Achados videofluoroscópicos na deglutição de pacientes com doença de Parkinson. Rev Esp Geriatr Gerontol. 2013,7:292-97.

Soria, F. S., Silva, R. G., \& Furkim, A. M. Análise acústica da deglutição orofaríngea utilizando Sonar Doppler. Braz J Otorhinolaryngol. 2016,82:39-46.

Souza, C. F. M., Almeida, H. C. P., Sousa, J. B., Costa, P. H., Silveira, Y. S. S., \& Bezerra, J. C. L. A doença de Parkinson e o processo de envelhecimento motor: uma revisão de literatura. Rev Neurocienc. 2011,19:718-23.

Takahashi, K., Groher, M. E., Michi, K. (1994). Methodology for detecting swallowing sounds. Springer. 9:54-96.

Taveira, K. V. M., Santos, R. S., Leão, B. L. C., Stechman Neto, J., Pernambuco, L., Silva, L. K. D., et al. (2018). Diagnostic validity of methods for assessment of swallowing sounds: a systematic review. Braz J Otorhinolaryngol. 84:638-52. 